\title{
Knowledge, attitude, and practice towards COVID-19 among Syrian people resident in Turkey
}

\author{
Saad Ahmed Ali Jadoo ${ }^{1^{*}}$, Ilker Dastan ${ }^{2}$, Mustafa Ali Mustafa Al-Samarrai ${ }^{3}$, Shukur Mahmood \\ Yaseen ${ }^{4}$, Asiyeh Abbasi ${ }^{5}$, Hassan Alkhdar ${ }^{6}$, Mohammed Al Saad ${ }^{7}$, Omar Mohamed Danfour ${ }^{8}$
}

\begin{abstract}
Background: Measuring knowledge, attitude, and practice towards COVID-19 helps policymakers observe knowledge gaps and provide key messages to people to act better against the pandemic. This study aims to assess the knowledge, attitude, and practice towards COVID-19 among Syrian people resident in Turkey.

Methods: A cross-sectional study designed to assess the knowledge, attitude, and practice towards COVID-19 among the Syrian people resident in Turkey. The data were collected via a web-based and self-administered questionnaire of 313 participants from 17-31 July 2020. SPSS version 16.0 was recruited to analyze the data using univariate and multivariable regression data analyses.

Results: Our finding as the first study among Syrian people resident in Turkey found a high rate of good knowledge, attitude, and practice towards COVID-19 accordingly with $83.0 \%, 72.0 \%, 84.0 \%$. Regression analysis showed that age-group of 45 years and more years, marital status of being married, female gender, living in urban area were significantly associated with upper knowledge score. Age-group of 45 years and more significantly associated with positive attitude score but inversely being married and unemployed statues significantly associated with a negative attitude. Regarding practice score, married and female people had better practice, but poor-rated health status was significantly associated with the weak practice.
\end{abstract}

Conclusion: Although our finding showed a good rate for knowledge, attitude, and practice towards COVID-19, but it needs to improve cause of many barriers on Syrian people resident in Turkey, such as living in a crowded place, distant from health care services, losing whole or part of their income due to COVID-19 as an economic crisis, different language barriers. Some groups like men, people living in a rural area, and those unemployed or lost their job should be exposed by timely and accurate knowledge.

Keywords: COVID-19, Knowledge, Attitude, Practice, Displaced, Refugees, Resident, Syrian people, Turkey

\section{Background}

Almost one year passed when Coronavirus disease 2019 (COVID-19) was first discovered in December 2019, in Wuhan city, China [1]. COVID-19 has spread widely and rapidly to other parts of the world. On March 11, 2020, the World Health Organization (WHO) declared that COVID-19 is a pandemic disease with no successful anti-viral treatment or vaccine yet [2]. However, the world appeared flustered and unprepared to face a global crisis collectively [3]. In this regard, many countries have decided to control the pandemic by implementing social distancing, quarantine, closing malls,

*Correspondence: drsaadalezzi@ gmail.com

${ }^{1}$ Department of Public Health, Faculty of Medicine, Bezmialem Vakif University, Istanbul, Turkey

Full list of author information is available at the end of the article shops, masjids, schools, universities, and jointly teaching medical care to people how to behave to prevent the adverse effects of coronavirus. Nevertheless, lessons learned from the severe acute respiratory syndrome (SARS coronavirus) or (SARS-CoV) and the influenza A virus subtype (N1H1) outbreaks suggested the precautionary behavior of the population depends on how people perceive risks and what actions they take [4]. People's reaction is different in terms of socioeconomic status, cultural differences, access to media [5], and the level of panic emotion [6]. Knowledge and behavior of the general public will determine the rate of spread in any country. The necessity of knowing about the level of knowledge towards COVID-19 for policymakers pushed countries to measure knowledge, attitude, and practice (KAP) measures 
towards COVID-19 in recent months. The results are not the same among the different groups of the population. For example, studies from China [7] and Saudi Arabia [8] showed an adequate level of knowledge towards COVID-19, but another country like Ethiopia [9] showed poor knowledge, so it is urgent to measure KAP to observe knowledge gaps to help people act better against the pandemic. On the other hand, some groups of population such as displaced, refugees, or migrants are at higher risk of weak behavior because of lack of information, limited financial means, and language barriers. Almost "79.5 million refugees and forcibly displaced people" in the world that more than three-quarters of them live in developing countries face problems with COVID-19 and humanitarian crises [10]. This study focuses on Syrians residing in Turkey, whose number of refugees and displaced persons exceeds 3.6 million, which is the largest number of registered Syrian refugees globally, and nearly half of them are children [11]. According to Cuevas et al. [12] report, $45.0 \%$ of the Syrian refugees live in poverty, and $14.0 \%$ live in extreme poverty. These figures show the need for urgent planning and implementation of policies for this part of the population because better tackling with pandemic needs an adequate level of knowledge and accurate attitude and practice levels towards the coronavirus. This paper investigates knowledge, attitude, and practice towards COVID-19 among the Syrian people resident in Turkey.

\section{Methods}

\section{Study Design and Sample}

A cross-sectional study designed to assess the knowledge, attitude, and practice towards COVID-19 among the Syrian people resident in Turkey. The data were collected via a webbased and self-administered questionnaire from 17-31 July 2020. The Google Docs Forms were recruited to create a link to the survey. The Google link was sent to Syrian people via Twitter and WhatsApp groups. This study is part of a large project with researchers' participation from Anbar and Diyala Universities in Iraq, Bezmialem Vakif University in Turkey, the Misrata University in Libya, and the World Health Organization. Briefly, the sampling technique and data collection process have been reported in detail previously [13].

\section{Inclusion and exclusion criteria}

All Syrian people living in Turkey (migrants, displaced, and refugees), 18 years of age or over, understand the questionnaire's content and agree to participate in the study. However, the study excluded the Syrian from outside Turkey, the non-Syrian displaced and refugees, and those aged $<18$.

\section{Sample size}

According to the Directorate General of Migration Management in Turkey, the total number of Syrian people inside and outside temporary accommodation centers estimated to be 3,610,022 [14]. The sample size calculator arrived at 385 participants, using a margin of error of $\pm 5 \%$, a confidence level of $95 \%$, a $50 \%$ response distribution, and 3,610,022 people [15].

\section{Study tool}

A semi-structured questionnaire was developed and tried by the authors earlier [13]. Considering adherence to the Centers for
Disease Control and Prevention (CDC) guidelines [16], The questionnaire was written in the English language, and then it was translated into the Arabic language. Twenty respondents (not included in the study) were recruited to test pilot the study tool. Content validation was performed with a content validity rate $[17,18]$. "The first page of the online questionnaire contained an assurance of the freedom to participate or withdraw and that all information and opinions submitted would be anonymous and confidential". The questionnaire contains four main sections. The first section contained information about the participants' social and demographic characteristics, including age, gender, marital status, education, employment, place of residence, income level, and self-rated health status. The second section of the questionnaire was designed to assess participants' knowledge of COVID-19. This section contained 20 items focusing on the ways of transmission of the Coronavirus, the clinical symptoms that appear on the infected person, the treatment protocol, and the groups most vulnerable to infection, in addition to information on isolation and prevention strategies, and control of the epidemic. In the third section of the questionnaire, there were 11 items to evaluate participants 'attitudes towards COVID-19, using a fivepoint Likert scale to determine the level of participants' agreement ranging from "1" 'Strongly disagree' to "5" 'Strongly agree'. The fourth section of the questionnaire has six questions recruited to evaluate respondents' practices and behaviors toward COVID-19.

\section{Independent variables}

For sociodemographic variables, gender was coded as one for females and zero for males. The age variable was reported in six groups: "18-24", "25-34", "35-44", "45-54", "55-64", and ">64" years old. Moreover, the age was categorized into two categorize codded zero for less than 45 years and coded one for 45 years and above. Marital status was captured as binary, and a value of one was used for married and zero for otherwise. Education was categorized and coded into zero (high academic) for college/university degree, postgraduate degree, and one (low educated) for high school or below. Work status categorized and the value of zero given to employed and value of one given to unemployed. Place of residency coded as zero for rural and one for urban. Monthly income (Turkish Lira, t 1 = USD 0.27) was divided into four categories: <USD 200, USD 200 to <400, USD 400 to1000, and more than USD1000. The self-rated health status was reported in a scale ranged from "very bad" to "very good" in a scale ranged from "1" to "5". Moreover, the self-rated health status was categorized into poor health (very bad, bad, moderate) and good health (good and very good).

\section{Dependent variables}

Respondents were asked to respond to knowledge items as either true or false, with an additional "do not know" option. Incorrect or uncertain (do not know) responses were given a score of zero, and correct answers were assigned a score. The total score for knowledge ranged from zero to 20, with high scores indicating better knowledge of COVID-19. Items were evaluated for internal reliability, using Cronbach's alpha. Cronbach's alpha coefficient was 0.70 , indicating internal reliability. In the section on attitudes, scores were calculated based on the respondents' answers to each attitudinal statement, 
$1=$ strongly disagree, $2=$ disagree, $3=$ undecided, $4=$ agree, and $5=$ strongly agree. Scores were calculated by averaging respondents' answers to the eleven statements. Total scores ranged from eleven to 55 , with high scores indicating positive attitudes. The Likert scales were assessed for internal reliability, using Cronbach's alpha. Cronbach's alpha coefficient was 0.81, indicating internal reliability. In the section on practices, respondents were asked to respond "yes" or "no" to the items. A score of one was given for answers that reflected good practice, and a score of zero was given for answers that reflected bad practice. The total score ranged from zero to six, with high scores indicating better practices.

\section{Statistical analysis}

Univariate analysis was recruited to tabulate the frequency of social and demographic statistics. An independent sample t-test and one-way analysis of variance (ANOVA) were used to assess differences in mean values for KAP scores. The overall mean differences were estimated using a Bartlett test [19]. A multivariable linear regression analysis was performed to identify factors related to knowledge, attitudes, and practice. All analyses were conducted using SPSS version 16.

\section{Results}

Demographic information

A total of 327 participants completed the questionnaire. After excluding 14 respondents who reported age less than 18 , the final sample consisted of 313 participants. As shown in table 1, of the total sample, $157(50.2 \%)$ were women. Most of the sample, 217 respondents $(69.3 \%)$, were in the age group less than 45 years old. Of the participants, 253 were married $(80.8 \%)$, and $60(19.2 \%)$ were unmarried (single, widow, divorce). More than half of the sample, $161(51.4 \%)$, had a low education level compared to $152(48.6 \%)$ had a college or university degree. Respondents were grouped according to monthly income, with 139 (44.4\%) in the US\$200-399 group, $66(21.1 \%)$ in the US\$400-1000 group and $60(19.2 \%)$ in the <US\$200 group, and $48(15.3 \%)$ in the >US\$1000 group. In terms of work status, 147 (47.0\%) were employed, 166 (53.0\%) were unemployed. Most of the respondents were urban residents $(262,83.7 \%)$. Most of the respondents perceived their health good $(130,41.5 \%)$ and very good $(95,30.4 \%)$, respectively.

KAP scores by social and demographic characteristics As shown in Table 2, the mean COVID-19 knowledge score was 16.53 ( $\mathrm{SD}=2.21$, range: $9-20$ ), and the overall accuracy rate for the knowledge test was $82.65 \%(16.53 / 20 * 100)$. The mean attitude score for COVID-19 was 39.09 (SD = 3.36, range: 11-55), indicating positive attitudes. The mean score for practices for COVID-19 was 5.04 (SD $=1.18$, range: $0-6$ ), indicating acceptable practices. Table 3 presents the mean of KAP scores towards COVID-19 by different social and demographic characteristics in Syria. Knowledge scores significantly differed across age-groups, categories of marital status, residence places, education level, income status, and health status. Age group and residency area are shown as an influential factor in Attitude scores. Marital status is the only influential factor in Practice scores $(\mathrm{P}<0.05)$.
Regression analysis showed that age-group of 45 years and more years $(\mathrm{P}=0.027)$, marital status of being married ( $\mathrm{P}$ $=0.000)$, female gender $(P=0.026)$, living in an urban area $(P$ $=0.000)$ were significantly associated with upper knowledge score. Age-group of 35 years and more years significantly associated with positive attitude score but inversely being married and unemployed statues significantly associated with a negative attitude. Regarding practice score, married and female people had better practice, but poor-rated health statues significantly associated with weak practice (Table 4).

Table 1 Social and demographic characteristics of the study participants $(\mathrm{n}=313)$.

\begin{tabular}{|c|c|c|}
\hline Variables & Category & Number (\%) \\
\hline \multirow[t]{2}{*}{ Gender } & Female & $157(50.2)$ \\
\hline & Male & $156(49.8)$ \\
\hline \multirow[t]{2}{*}{ Age group } & 45 years and more & $96(30.7)$ \\
\hline & $<45$ years & $217(69.3)$ \\
\hline \multirow[t]{2}{*}{ Marital status } & Married & $253(80.8)$ \\
\hline & Single & $60(19.2)$ \\
\hline \multirow[t]{2}{*}{ Education } & Low education & $161(51.4)$ \\
\hline & High education & $152(48.6)$ \\
\hline \multirow[t]{2}{*}{ Area Residence } & Urban & $262(83.7)$ \\
\hline & Rural & $51(16.3)$ \\
\hline \multirow[t]{2}{*}{ Employment statues } & Unemployed & $166(53.0)$ \\
\hline & Employed & $147(47.0)$ \\
\hline \multirow[t]{4}{*}{ Level of income } & $<$ US $\$ 200$ & $60(19.2)$ \\
\hline & US\$200-399 & $139(44.4)$ \\
\hline & US\$400-1000 & $66(21.1)$ \\
\hline & $>\mathrm{US} \$ 1000$ & $48(15.3)$ \\
\hline \multirow[t]{5}{*}{ Self-rated health status } & Very bad & $9(2.9)$ \\
\hline & $\mathrm{Bad}$ & $32(10.2)$ \\
\hline & Moderate & $47(15.0)$ \\
\hline & Good & $130(41.5)$ \\
\hline & Very good & $95(30.4)$ \\
\hline
\end{tabular}

As presented in table 5, more than $90.0 \%$ of the total sample had accurate knowledge related to "washing hands, wearing medical masks, avoiding touching their eyes, nose, and mouth with the unwashed hand ", "clinical symptoms and its importance", "spreads through cough and sneeze by infected people", "elderly people, people with chronic diseases in higher risk" and "the importance of healthy food and drinking water and isolation". However, $38.0 \%$ of them have insufficient knowledge about antibiotics' effectiveness, and $26.0 \%$ do not have accurate knowledge about children affected by COVID19. More than $90.0 \%$ of respondents "Maintaining a reasonable distance" and "washing hands" protect individuals and society from coronavirus. $82.0 \%$ reported that they do not believe in staying at home as an effective preventive measure. $20.0 \%$ of respondents thought that coronavirus would not be controlled, and $42.0 \%$ feel that it was too late for the implication of lockdown at the beginning of the epidemic. Just $70.0 \%$ of them thought the Turkey government's strict measures were enough to win the battle against coronavirus. Also, $82.0 \%$ of participants thought complying with the instructions of the National Safety Committee of the Ministry of Health will prevent coronavirus spread. $19.0 \%$ thought that the announced number related to infected and dead persons due to coronavirus 
are exaggerated (Table 6). In terms of practice towards COVID19 that are presented in Table $7,17.0 \%$ of participants had attended a social event involving many people, $31.0 \%$ were in a crowded place, $83.0 \%$ did not avoid social behavior such as shake hands or kiss people, $11.0 \%$ did not think seriously about social distancing, $7.7 \%$ were not interested about washing hands after going to a public place, or after blowing their nose, coughing, or sneezing, $13.4 \%$ were not interested about washing things from outside the home.

Table 2 Number of questions, range, scores, and levels of knowledge, attitude, and practice $(\mathrm{n}=313)$

\begin{tabular}{llllc}
\hline Variables & Number of questions & Range of score & Total scores $($ mean \pm SD) & Accuracy rate $(\%)$ \\
\hline Knowledge & 20 & $9-20$ & $16.53 \pm 2.21$ & 82.65 \\
Attitude & 11 & $11-55$ & $39.09 \pm 3.36$ & 71.07 \\
Practice & 6 & $0-6$ & $5.04 \pm 1.18$ & 84.00 \\
\hline
\end{tabular}

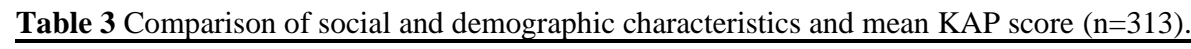

\begin{tabular}{|c|c|c|c|c|c|c|c|c|c|c|c|c|}
\hline \multirow[t]{2}{*}{ Variables } & & \multicolumn{2}{|c|}{ Total } & \multicolumn{3}{|c|}{ Knowledge } & \multicolumn{3}{|c|}{ Attitude } & \multicolumn{3}{|c|}{ Practice } \\
\hline & & $\mathrm{n}$ & $\%$ & Mean & SD & $P$ & Mean & $\mathrm{SD}$ & $P$ & Mean & $\mathrm{SD}$ & $P$ \\
\hline \multirow[t]{2}{*}{ Gender } & Female & 157 & 50.2 & 17.0 & 2.0 & 0.000 & 39.5 & 3.7 & 0.040 & 5.2 & 1.1 & 0.028 \\
\hline & Male & 156 & 49.8 & 16.0 & 2.3 & & 38.7 & 3.6 & & 4.9 & 1.2 & \\
\hline \multirow[t]{2}{*}{ Age group } & $\geq 45$ years & 96 & 30.7 & 16.7 & 2.6 & 0.298 & 39.3 & 4.3 & 0.510 & 5.1 & 1.1 & 0.513 \\
\hline & $<45$ years & 217 & 69.3 & 16.4 & 2.0 & & 39.0 & 3.3 & & 5.0 & 1.2 & \\
\hline \multirow[t]{2}{*}{ Marital status } & Married & 253 & 80.8 & 17.0 & 2.1 & 0.000 & 38.9 & 3.5 & 0.031 & 5.1 & 1.1 & 0.000 \\
\hline & Single & 60 & 19.2 & 14.7 & 1.8 & & 40.0 & 4.1 & & 4.5 & 1.5 & \\
\hline \multirow[t]{2}{*}{ Education level } & Low education & 161 & 51.4 & 16.3 & 2.4 & 0.024 & 39.2 & 4.0 & 0.495 & 5.1 & 1.1 & 0.715 \\
\hline & High education & 152 & 48.6 & 16.8 & 2.0 & & 38.9 & 3.3 & & 5.0 & 1.2 & \\
\hline \multirow[t]{2}{*}{ Residency } & Urban & 262 & 83.8 & 17.1 & 1.7 & 0.000 & 39.1 & 3.6 & 0.854 & 5.1 & 1.1 & 0.198 \\
\hline & Rural & 51 & 16.3 & 13.5 & 1.8 & & 39.0 & 3.8 & & 4.8 & 1.4 & \\
\hline \multirow[t]{2}{*}{ Employment } & Unemployed & 166 & 53.0 & 16.2 & 2.4 & 0.008 & 38.6 & 3.8 & 0.019 & 5.0 & 1.2 & 0.481 \\
\hline & Employed & 147 & 47.0 & 16.9 & 2.0 & & 39.6 & 3.5 & & 5.1 & 1.1 & \\
\hline \multirow[t]{4}{*}{ Level of income } & $<$ the US $\$ 200$ & 60 & 19.2 & 15.6 & 2.5 & 0.001 & 38.6 & 3.8 & 0.420 & 5.1 & 1.3 & 0.076 \\
\hline & US\$200-399 & 139 & 44.4 & 16.6 & 2.1 & & 39.4 & 4.0 & & 5.1 & 1.1 & \\
\hline & US\$400-1000 & 66 & 21.1 & 16.6 & 2.2 & & 39.3 & 3.1 & & 4.7 & 1.3 & \\
\hline & $>\mathrm{US} \$ 1000$ & 48 & 15.3 & 17.5 & 1.7 & & 38.6 & 3.2 & & 5.2 & 0.9 & \\
\hline \multirow[t]{5}{*}{ Self-rated health status } & Very bad & 9 & 2.9 & 18.7 & 1.9 & 0.001 & 37.9 & 3.9 & 0.367 & 5.1 & 0.9 & 0.180 \\
\hline & $\mathrm{Bad}$ & 32 & 10.2 & 16.3 & 2.8 & & 38.6 & 4.2 & & 5.5 & 0.9 & \\
\hline & Moderate & 47 & 15.0 & 16.0 & 2.1 & & 39.7 & 4.3 & & 5.2 & 0.9 & \\
\hline & Good & 130 & 41.5 & 16.3 & 2.1 & & 39.3 & 3.4 & & 5.0 & 1.2 & \\
\hline & Very good & 95 & 30.4 & 17.0 & 2.0 & & 38.7 & 3.5 & & 5.0 & 1.4 & \\
\hline
\end{tabular}

$\underline{\text { Table } 4 \text { Regression results of KAP-related factors for COVID-19 }(n=313)}$

\begin{tabular}{|c|c|c|c|c|c|c|c|c|}
\hline \multirow[t]{2}{*}{ Variable } & \multirow[t]{2}{*}{ B } & \multirow[t]{2}{*}{ SE } & \multirow[t]{2}{*}{ Beta } & \multirow[t]{2}{*}{$\mathrm{t}$} & \multirow[t]{2}{*}{$P$-value } & $95 \% \mathrm{CI}$ & \multirow[t]{2}{*}{ Tolerance } & \multirow[t]{2}{*}{ VIF } \\
\hline & & & & & & lower-Upper & & \\
\hline \multicolumn{9}{|l|}{ Knowledge (Durbin-Watson=1.678) } \\
\hline 45 years and more (vs $<45$ years) & 0.455 & 0.205 & 0.095 & 2.220 & 0.027 & $(0.052,0.859)$ & 0.993 & 1.007 \\
\hline Married (VS single) & 1.351 & 0.252 & 0.241 & 5.356 & 0.000 & $(0.855,1.848)$ & 0.902 & 1.109 \\
\hline Female (VS Male) & 0.435 & 0.194 & 0.099 & 2.240 & 0.026 & $(0.053,0.817)$ & 0.943 & 1.061 \\
\hline Urban (VS Rural) & 3.060 & 0.276 & 0.512 & 11.071 & 0.000 & $(2.516,3.602)$ & 0.853 & 1.172 \\
\hline \multicolumn{9}{|l|}{ Attitude (Durbin-Watson= 1.743) } \\
\hline Married (VS single) & -1.219 & 0.519 & -0.131 & -2.350 & 0.019 & $(-2.240,0.198)$ & 0.995 & 1.005 \\
\hline Unemployed (VS Employed) & -1.031 & 0.409 & -0.141 & -2.520 & 0.012 & $(-1.837,0.226)$ & 0.959 & 1.105 \\
\hline \multicolumn{9}{|l|}{ Practice (Durbin-Watson= 1.748) } \\
\hline Married (VS single) & 0.599 & 0.165 & 0.200 & 3.639 & $0^{*} .000$ & $(0.275,0.923)$ & 0.995 & 1.005 \\
\hline Female (VS Male) & 0.299 & 0.131 & 0.127 & 2.289 & 0.023 & $(0.042,0.556)$ & 0.981 & 1.020 \\
\hline $\begin{array}{l}\text { Poor-rated health } \\
\text { (vs Good -rated health) }\end{array}$ & -0.332 & 0.144 & -0.127 & -2.298 & 0.022 & $(-0.616,0.048)$ & 0.998 & 1.015 \\
\hline
\end{tabular}




\section{Discussion}

Like other KAP studies in recent months, our study has several implications for public health policy and research. The findings of this study provide important and timely insights into how Syrian people resident in Turkey understand information towards COVID-19 and how to practice. Our finding as first KAP study among Syrian people resident in Turkey found a higher rate $(83.0 \%)$ of good knowledge towards COVID-19 when comparing with studies from Iraq [13], Egypt and Nigeria (61.6\%) [20], and Bangladesh (48.3\%) [21], however, the rates are similar to results reported in China (90.0\%) [22], Cameroon (84.19\%) [23], Saudi Arabi (81.64\%) [24], Malaysia (80.5\%) [25]. This higher rate of knowledge towards COVID-19 can be because of high exposure to Turkey's information for the general population, including the international residents. Another reason could be that $84.0 \%$ of the participants live in an urban area, and $49.0 \%$ of them held an academic degree. Although more than $90.0 \%$ of respondents had accurate knowledge related to "washing hands, wearing medical masks, isolation and so on", however, $38.0 \%$ of them have poor knowledge about the effectiveness of antibiotics for treatment against COVID-19, and $26.0 \%$ of them did not have accurate knowledge about children being affected by COVID-19 as shown in other countries like Saudi Arabia [24] and Jourdan [26]. Our findings suggest that Syrian people living in urban areas in Turkey are more than 45 years old, married, and have good knowledge of COVID-19. Results of this study showed a high attitude score towards COVID-19 among the Syrian people resident in Turkey. Based on the questionnaire results, just $70.0 \%$ of respondents thought the Turkish government's strict measures were sufficient to win the battle against COVID-19, and $42.0 \%$ of them feel that it was too late for the implication of lockdown at the beginning of the epidemic. Since $82.0 \%$ reported that they do not believe in staying at home as effective preventive measure, further government encouragement is required. Syrian people in Turkey who are older than 45 have positive attitude, but married and unemployed people have negative attitude.

Although most of the participants took precautions to avoid contamination by COVID-19, our study showed that $31.0 \%$ of participants went to a crowded place, and $16.6 \%$ attended a social event (such as a wedding party, funeral parlor, etc.) recently. It shows an urgent plan for implementing control measures by local governments and limit commuting at the time of the outbreak. Taking limitation measures are necessary to prevent the spread of coronavirus from interrupting transmission. A better practice is associated with being married and female gender, but people with poor health conditions did not have good practice compared to healthier people. Based on our findings, some certain demographic groups such as men, young people, and those living in rural areas need to receive medical care information more than others. Our findings are similar to the results from other countries. For example, most Chinese [22] residents of a relatively high socioeconomic status, particularly women, are knowledgeable about COVID19, hold optimistic attitudes, and have appropriate practices towards COVID-19. In Iraq [13], the higher educated, urban residents, employed, and those having an income level of US\$ 400 or more were significantly associated with upper knowledge score. Another study from Saudi Arabia [24] showed that most of the study participants were knowledgeable about COVID-19, which indicated a high level of knowledge, optimistic attitudes, and acceptable practices. Men have less knowledge, less optimistic attitudes, and less good practice towards COVID-19 than women. They also found that older adults are likely to have better knowledge and practices than younger people. Unlike findings from Iraq [13], where the respondents with good incomes have negative attitudes about coronavirus pandemic; however, our results showed that unemployment variable was significantly associated with lower attitude score. It can be related to having a low-income level due to being unemployed and also, a large share of migrants works under informal arrangements without social security coverage. Moreover, a report published by the International Red Cross and Red Crescent Movement showed that about $70.0 \%$ of refugees surveyed in Turkey reported having lost their jobs since the start of the coronavirus pandemic [27]. On the other hand, having low level of income can lead to insufficient knowledge. It can be a result of people who are in the wealthier situation are eager to collect information more than others, and economic status can push people for better and timely action to prevent COVID-19, and inversely poor people have many other issues to deal with them such as food insecurity, new problems cause of losing jobs due to COVID-19. So COVID-19 control measures should not come at the cost of access to urgently needed healthcare, and governments must ensure restrictions in camp, detention, or reception settings and do not block people from accessing healthcare. Another problem is the challenge of misinformation and misunderstanding caused by limited competence in the Turkish language and other foreign language barriers. Although Turkey made some progress in improving knowledge toward COVID-19, such as services advisor, sending a message through WhatsApp, and sharing information in Facebook in Arabic [28], improving suitable communication platforms is needed urban and rural for conveying information about COVID-19. In this context, strengthening communication and awareness of acceptable practices are vital in limiting transmission of the new coronavirus among the Syrian and other refugee and migrated community in Turkey. Similar to other studies from Iraq [13], China [22], and Saudi Arabia [24], there is a positive correlation between the level of education and knowledge regarding COVID-19. People with a low level of education cannot communicate with others easily, and also, there is some difficulty for them to use social media for tracking news. Hence, it is urgent to inform this part of the population in other ways.

This study complaint of some limitations. The survey is conducted as a web-based survey using Twitter and WhatsApp. Therefore, there is a probability that a part of the population was not included in the survey, such as people without smartphones, having no internet access, illiterate people, or people with disabilities in reading and collecting information in the current survey. This may overestimate the overall results because respondents may be more knowledgeable and have better practices towards general pandemics. Although this study is devoted to Syrians residing in Turkey, this study's results may not be generalizable to the rest of immigrants and refugees from other countries due to the different cultural and socio and economic factors. 


\section{Conclusion}

The level of knowledge, attitude, and practice of the Syrian people resident in Turkey towards COVID-19 were good compared to some neighboring countries. Several sociodemographic and economic variables such as gender, education, employment, residency, and income appeared as KAP determinants towards COVID-19. Researchers expect that this study's results will help health authorities in Turkey formulate appropriate measures to confront the spread of COVID-19 among immigrants and residents of other nationalities.

Table 5 Correct responses to knowledge statements regarding COVID-19 (n=313)

\begin{tabular}{|c|c|c|}
\hline No. & Statement & $\mathrm{N}(\%)$ \\
\hline 1 & Corona is a viral disease that spreads from person to person at a distance of up to two meters ( 6 feet) & $229(73.2)$ \\
\hline 2 & Corona spreads through respiratory droplets that occur when infected people cough and sneeze. & $307(98.1)$ \\
\hline 3 & $\begin{array}{l}\text { Corona infection may occur by touching or kissing the contaminated surfaces or objects and then touching the mouth, nose, } \\
\text { or possibly the eyes. }\end{array}$ & $300(85.8)$ \\
\hline 4 & Eating or touching wild animals can lead to infection with the Coronavirus. & 124(39.6) \\
\hline 5 & People infected with COVID-19 cannot transmit the virus to others when a fever is not present. & 218(69.6) \\
\hline 6 & The main clinical symptoms of COVID-19 are fever, fatigue, dry cough, myalgia, and shortness of breath. & $301(96.2)$ \\
\hline 7 & Unlike the common cold, congestion, runny nose, and sneezing are less common in people infected with COVID-19. & 224(71.6) \\
\hline 8 & Antibiotics are effective in treating COVID-19. & $196(62.2)$ \\
\hline 9 & $\begin{array}{l}\text { Currently, there is no effective cure for COVID-19, but early symptomatic and supportive treatment can help most patients } \\
\text { recover from the diseases. }\end{array}$ & 286(91.4) \\
\hline 10 & $\begin{array}{l}\text { The elderly and people who suffer from serious chronic diseases such as heart or lung disease and diabetes have a doubled } \\
\text { risk of developing serious complications from developing a COVID-19. }\end{array}$ & $304(97.1)$ \\
\hline 11 & Pregnant women are more susceptible to infections than non-pregnant women. & $108(34.5)$ \\
\hline 12 & Children are less likely to be infected with COVID- 19 than adults. & $232(74.1)$ \\
\hline 13 & Children or young people do not need to take protective measures against COVID-19 transmission. & $277(88.5)$ \\
\hline 14 & $\begin{array}{l}\text { people must wash their hands with soap and water or use a hand sanitizer containing at least } 60 \% \text { alcohol for at least } 20 \\
\text { seconds. After being in a public place, after nose-blowing, coughing, or sneezing, }\end{array}$ & 301(96.2) \\
\hline 15 & As a precaution, people should avoid touching their eyes, nose, and mouth with unwashed hands. & 308(98.4) \\
\hline 16 & Wearing medical masks is very important to prevent corona infection. & 294(93.9) \\
\hline 17 & People should only wear a mask if they are infected with the virus or care for someone with suspected COVID-19 infection. & $216(69.0)$ \\
\hline 18 & Healthy food and drinking water strengthen the body's immunity and resistance against COVID-19. & 296(94.6) \\
\hline 19 & Isolation and treatment of people infected with the COVID-19 are effective ways to reduce the virus's spread. & $308(98.4)$ \\
\hline 20 & $\begin{array}{l}\text { People being in contact with someone infected with COVID-19 should be immediately quarantined, in an appropriate } \\
\text { location, for a general observation period of } 14 \text { days. }\end{array}$ & $306(97.8)$ \\
\hline
\end{tabular}

Table 6 Responses to attitudinal statements regarding COVID-19 $(\mathrm{n}=313)$

\begin{tabular}{|c|c|c|c|c|c|c|}
\hline No. & Statements & $\begin{array}{l}\text { Strongly } \\
\text { agree }\end{array}$ & Agree & $\begin{array}{l}\text { Do not } \\
\text { know }\end{array}$ & Disagree & $\begin{array}{l}\text { Strongly } \\
\text { disagree }\end{array}$ \\
\hline 1 & $\begin{array}{l}\text { Maintaining a reasonable distance from others is very important to avoid } \\
\text { the spread of coronavirus. }\end{array}$ & $151(48.2)$ & 151(48.2) & $7(2.2)$ & $0(0)$ & $4(1.3)$ \\
\hline 2 & $\begin{array}{l}\text { Hand washing is necessary to protect individuals and society from the } \\
\text { coronavirus. }\end{array}$ & $166(53.0)$ & $138(44.1)$ & $5(1.6)$ & $0(0)$ & $4(1.3)$ \\
\hline 3 & $\begin{array}{l}\text { Staying at home is an effective preventive measure to protect individuals } \\
\text { and society from coronavirus exposure. }\end{array}$ & $88(28.1)$ & $168(53.7)$ & $16(5.1)$ & $37(11.8)$ & $4(1.3)$ \\
\hline 4 & I think the Corona epidemic can be successfully controlled. & $32(10.2)$ & 125(39.9) & 92(29.4) & $52(16.6)$ & $12(3.8)$ \\
\hline 5 & $\begin{array}{l}\text { The strict measures taken by Turkey government are sufficient to win the } \\
\text { battle against coronavirus. }\end{array}$ & $45(14.4)$ & $175(55.9)$ & $58(18.5)$ & $27(8.6)$ & $8(2.6)$ \\
\hline 6 & $\begin{array}{l}\text { Complying with the National Safety Committee of the Ministry of Health } \\
\text { instructions will prevent the spread of corona. }\end{array}$ & $72(23.3)$ & $185(59.1)$ & $41(13.1)$ & $14(4.5)$ & $1(0.3)$ \\
\hline 7 & $\begin{array}{l}\text { The complete lockdown was an effective measure to prevent the spread } \\
\text { of coronavirus, but it negatively affected the family's economic situation. }\end{array}$ & $126(40.3)$ & $156(49.8)$ & $11(3.5)$ & $19(6.1)$ & $1(0.3)$ \\
\hline 8 & $\begin{array}{l}\text { I think the figures that announced the number of infected people and the } \\
\text { number of deaths due to coronavirus are exaggerated. }\end{array}$ & $16(5.1)$ & $44(14.1)$ & $112(35.8)$ & $99(31.6)$ & $42(13.4)$ \\
\hline 9 & $\begin{array}{l}\text { I still think that Corona Virus is a hoax, and there is no need to take } \\
\text { precautions. }\end{array}$ & $3(1.0)$ & $4(1.3)$ & $31(9.9)$ & $120(38.3)$ & $155(49.5)$ \\
\hline 10 & I have a growing concern about the second peak of coronavirus cases & $35(11.2)$ & 141(45.0) & $85(27.2)$ & $46(14.6)$ & $6(1.9)$ \\
\hline 11 & $\begin{array}{l}\text { When the lockdown introduced at the beginning of the epidemic, I felt it } \\
\text { was implemented too late }\end{array}$ & $33(10.5)$ & $100(31.9)$ & $61(19.5)$ & $110(35.1)$ & $9(2.9)$ \\
\hline
\end{tabular}


Table 7 Responses to practice statements regarding COVID-19 (n=313)

\begin{tabular}{|c|c|c|c|}
\hline No. & Statement & Yes & No \\
\hline 1 & $\begin{array}{l}\text { Have you recently attended a social event (such as a wedding party, funeral parlor, etc.) involving } \\
\text { many people? }\end{array}$ & $52(16.6)$ & $261(83.4)$ \\
\hline 2 & Have you recently been in a crowded place? & $96(30.8)$ & $217(69.3)$ \\
\hline 3 & $\begin{array}{l}\text { Have you recently avoided shaking hands or kissing or any social behavior that calls for meeting } \\
\text { and closeness? }\end{array}$ & $53(16.9)$ & $260(83.1)$ \\
\hline 4 & $\begin{array}{l}\text { Have you seriously thought about practicing social distancing and leaving a distance when talking } \\
\text { to people? }\end{array}$ & $279(89.1)$ & $34(10.9)$ \\
\hline 5 & $\begin{array}{l}\text { Recently, have you become more interested in washing your hands with soap and water frequently, } \\
\text { for at least } 20 \text { seconds, especially after going to a public place or after blowing your nose, coughing, } \\
\text { or sneezing? }\end{array}$ & $289(92.3)$ & $24(7.7)$ \\
\hline 6 & $\begin{array}{l}\text { Recently, have you become more interested in washing things that you bring from outside the home, } \\
\text { including fruits and vegetables? }\end{array}$ & $271(86.6)$ & $42(13.4)$ \\
\hline
\end{tabular}

\section{Abbreviation}

COVID-19: Coronavirus; N1H1: Influenza A Virus Subtype; SARS coronavirus) or (SARS-CoV: Severe Acute Respiratory Syndrome; CDC: Centers for Disease Control and Prevention; KAP: Knowledge, Attitude, Practice; TL Turkish Lira; USD: United State Dollar; ANOVA: One-Way Analysis of Variance

\section{Declaration}

Acknowledgment

We would like to thank Mr. Anmar Shukur Mahmood for his great efforts in helping to prepare the questionnaires and the necessary links and distribution through the social networking sites. We also extend our thanks to all respondents to the survey during the Coronavirus pandemic.

\section{Funding}

The authors received no financial support for their research, authorship, and/or publication of this article.

\section{Availability of data and materials}

Data will be available by emailing drsaadalezzi@gmail.com

\section{Authors' contributions}

Saad Ahmed Ali Jadoo (SAAJ) is the principal investigator of this manuscript (Original manuscript) who designed the study and coordinated all aspects of the research including the study design, analysis, and interpretation of data, drafting the work, writing the manuscript, and reviewed and approved the manuscript. SAAJ, ID, MAMA, SMY, AA contributed to the study concept, design, writing, reviewing, editing, and approving the manuscript in its final form. $\mathrm{HH}$, and MA contributed to data collection. OMD contributed to drafting the manuscript. All authors have read and approved the final manuscript.

\section{Ethics approval and consent to participate}

We conducted the research following the Declaration of Helsinki, and the protocol was approved by the Ethics Committee of the Scientific Issues and Postgraduate Studies Unit (PSU), College of Medicine, University of Anbar (Ref: SR/368 at 19-July-2020); the Ethics Committee of the College of Medicine, Diyala University (Ref: 1250 at 15-July-2020); National Cancer Institute, Misrata, Libya (Ref: 0000 at 91-August-2020). Moreover, web-based informed consent obtained from each participant after explanation of the study objectives and the guarantee of secrecy.

\section{Consent for publication}

Not applicable

\section{Competing interest}

The author declares that he has no competing interests.

\section{Open Access}

This article is distributed under the terms of the Creative Commons $\begin{array}{llll}\text { Attribution } & 4.0 & \text { International License }\end{array}$ (http://creativecommons.org/licenses/by/4.0/), which permits unrestricted use, distribution, and reproduction in any medium, provided you give appropriate credit to the original author(s) and the source, provide a link to the Creative Commons license, and indicate if changes were made. The Creative Commons Public Domain Dedication waiver (http://creativecommons.org/publicdomain/zero/1.0/) applies to the data made available in this article, unless otherwise stated.

Author details

${ }^{1}$ Department of Public Health, Faculty of Medicine, Bezmialem Vakif University, Istanbul, Turkey. ${ }^{2}$ World Health Organization, WHO Country Office, VEFA Center, of. № 605, 6th floor 37/1 Bokhtar Street, Dushanbe 734019, Tajikistan. ${ }^{3}$ Ddepartment of family and community medicine, Faculty of Medicine, Anbar University, Anbar, Iraq. ${ }^{4}$ Department of Anatomy, Molecular Genetics, Faculty of Medicine, University of Diyala, Diyala, Iraq. ${ }^{5}$ World Health Organization, Headquarters in Geneva, Department of Health Governance and Financing, Avenue Appia 20, 1211 Geneva, Switzerland. ${ }^{6}$ Faculty of Pharmacy, Istanbul University, Istanbul, Turkey. ${ }^{7}$ Department of Community Health, Faculty of Medicine, Universiti Kebangsaan Malaysia Medical Centre, Kuala Lumpur, Malaysia. ${ }^{8}$ Department of Surgery, Anaesthesia and Intensive Care Unit, Faculty of Medicine, Misurata University, National Cancer Institute, Misurata, Libya.

\section{Article Info}

Received: 24 August 2020

Accepted: 05 October 2020

Published: 29 December 2020

\section{References}

1. World Health Organization, Novel Coronavirus 2019-nCoV) SITUATION REPORT -1, 21 JANUARY 2020. Available from: https://www.who.int/docs/default-source/coronaviruse/situation- 
reports/20200121-sitrep-1-2019-ncov.pdf [Accessed on 08 September 2020].

2. World Health Organization, WHO Director-General's opening remarks at the media briefing on COVID-19 - 11 March 2020 Available from: https://www.who.int/directorgeneral/speeches/detail/who-director-general-s-opening-remarksat-the-media-briefing-on-covid-19---11-march-2020 [Accessed on 15 August 2020].

3. Ali Jadoo SA. Was the world ready to face a crisis like COVID19? Journal of Ideas in Health2020;3(1):123-4. https://doi.org/10.47108/jidhealth.Vol3.Iss1.45

4. Ali Jadoo SA. The second wave of COVID-19 is knocking at the doors: have we learned the lesson? Journal of Ideas in Health 2020;3(Special1):183-4

https://doi.org/10.47108/jidhealth.Vol3.IssSpecial1.72

5. Zwart O, Veldhuijzen IK, Richardus JH, Brug J. Monitoring of risk perceptions and correlates of precautionary behaviour related to human avian influenza during 2006 - 2007 in the Netherlands: results of seven consecutive surveys. BMC Infect Dis. 2010 10:114. https://doi.org/10.1186/1471-2334-10-114

6. Person B, Sy F, Holton K, Govert B, Liang A. National Center for Infectious Diseases/SARS Community Outreach Team. Fear and stigma: the epidemic within the SARS outbreak. Emerg Infect Dis. 2004;10(2):358-63. https://doi.org/10.3201/eid1002.030750

7. Zhong BL, Luo W, Li HM, Zhang QQ, Liu XG, Li WT, Li Y. Knowledge, attitudes, and practices towards COVID-19 among Chinese residents during the rapid rise period of the COVID-19 outbreak: a quick online cross-sectional survey. Int J Biol Sci. $2020 \quad$ Mar https://doi.org/10.7150/ijbs.45221

$15 ; 16(10): 1745-1752$

Al-Hanawi MK, Angawi K, Alshareef N, Qattan AMN, Helmy HZ, Abudawood Y, et al. knowledge, attitude and practice toward COVID-19 among the public in the kingdom of Saudi Arabia: a cross-sectional study. Front Public Health. 2020; 8:217. https://doi.org/10.3389/fpubh.2020.00217

9. Akalu Y, Ayelign B, Molla MD. knowledge, attitude and practice towards COVID-19 among chronic disease patients at Addis Zemen Hospital, Northwest Ethiopia. Infect Drug Resist. 2020; 13:1949-1960. https://doi.org/10.2147/IDR.S258736

10. UNHCR, Operational portal, global overview. https://data2.unhcr.org/en/situations/covid-

19?\# ga=2.126089486.225943309.1600281096-

1891965831.1600281096 [Accessed on 7 November 2020]

11. Türkiye Cumhuriyeti Içişleri Bakanlığı, Göç İdaresi Genel Müdürlüğü, Geçici Koruma, geçici barınma merkezleri içinde ve dışında bulunan Suriyeliler sayısı (Republic of Turkey, Ministry of interior, Directorate General of Migration Management,Temporary Protection, The number of Syrians inside and outside temporary accommodation centers) 28 June 2020. Available from: https://www.goc.gov.tr/gecici-koruma5638 [Accessed on 5 July 2020].

12. Cuevas $\mathrm{PF}$, Inan $\mathrm{OK}$, Twose $\mathrm{A}$, Celik $\mathrm{C}$. vulnerability and protection of refugees in Turkey: findings from the rollout of the largest humanitarian cash assistance program in the world. World Bank and World Food Programme, 2019. (C) World Bank and World Food Programme. https://openknowledge.worldbank.org/handle/10986/31813

13. Ali Jadoo SA, Alhusseiny A, Yaseen S, Al-Samarrai M, Al-Rawi R, Al-Delaimy A, Abed M, Hassooni H. Knowledge, attitude, and practice toward COVID-19 among Iraqi people: a web-based cross-sectional study. Journal of Ideas in Healthjidhealth 2020;3(Special2):258-65.

https://doi.org/10.47108/jidhealth.Vol3.IssSpecial\%202.59

14. Türkiye Cumhuriyeti Içişleri Bakanlığı, Göç İdaresi Genel Müdürlüğü, Geçici Koruma, geçici barınma merkezleri içinde ve dışında bulunan Suriyeliler sayısı (Republic of Turkey, Ministry of interior, Directorate General of Migration Management,Temporary Protection, The number of Syrians inside and outside temporary accommodation centers) 28 June 2020. Available from: https://www.goc.gov.tr/gecici-koruma5638 [Accessed on 5 July 2020].

15. RAOSOFT. Sample Size Calculator 2020. Available online at http://www. raosoft.com/samplesize.html (Accessed on 5 July 2020).

16. CDC. Centers for Disease Control and Prevention: Coronavirus (COVID-19) 2020. Available from: https://www.cdc.gov/coronavirus/2019-nCoV/ index.html [Accessed on 6 September 2020].
17. Ali Jadoo SA, Aljunid SM, Seher Nur Sulku, Al-Dubai SAR, Wan Puteh SE, Ahmed Z, Abdul Manaf MR, Sulong SB, Nur AM. Health system reform from the people's point of view: development of reliable and valid questionnaire. Malaysian Journal of Public Health Medicine 2013;13(2):65-76. 26.

18. Ali Jadoo SA, Sulku SN, Aljunid SM, Dastan I. Validity and reliability analysis of knowledge of, attitude toward and practice of a case-mix questionnaire among Turkish healthcare providers. JHEOR. 2014;2(1):96-107

19. O'brien RG. A general ANOVA method for robust tests of additive models for variances. J Am Statist Assoc.1979; 74:87780. https://doi.org/10.1080/01621459.1979.10481047

20. Hager E, Odetokun IA, Bolarinwa O, Zainab A, Okechukwu O, Al-Mustapha AI. Knowledge, attitude, and perceptions towards the 2019 coronavirus pandemic: A bi-national survey in Africa. PLOS ONE 2020; 15(7): https://doi.org/10.1371/journal.pone.0236918

21. Ferdous MZ, Islam MS, Sikder MT, Mosaddek ASM, ZegarraValdivia JA, Gozal D.Knowledge, attitude, and practice regarding COVID-19 outbreak in Bangladesh: An online-based crosssectional study. PLOS ONE2020; 15(10): e0239254. https://doi.org/10.1371/journal.pone.0239254

22. Zhong BL, Luo W, Li HM, Zhang QQ, Liu XG, Li WT, Li Y. Knowledge, attitudes, and practices towards COVID-19 among Chinese residents during the rapid rise period of the COVID-19 outbreak: a quick online cross-sectional survey. Int J Biol Sci. $2020 \quad$ Mar 15;16(10):1745-1752. https://doi.org/10.7150/ijbs.45221

23. Ngwewondo A, Nkengazong L, Ambe LA, Ebogo JT, Mba FM, Goni HO, Nyunaï N, Ngonde MC, Oyono JE. Knowledge, attitudes, practices of/towards COVID 19 preventive measures and symptoms: A cross-sectional study during the exponential rise of the outbreak in Cameroon. PLoS Negl Trop Dis. 2020 Sep 4;14(9): e0008700. https://doi.org/10.1371/journal.pntd.0008700

24. Al-Hanawi MK, Angawi K, Alshareef N, Qattan AMN, Helmy HZ, Abudawood Y, Alqurashi M, Kattan WM, Kadasah NA, Chirwa GC, Alsharqi O. Knowledge, attitude and practice toward COVID-19 among the public in the kingdom of saudi arabia: a cross-sectional study. Front Public Health. 2020 May 27; 8:217. https://doi.org/10.3389/fpubh.2020.00217

25. Azlan AA, Hamzah MR, Sern TJ, Ayub SH, Mohamad E. Public knowledge, attitudes and practices towards COVID-19: A crosssectional study in Malaysia. PLoS One. 2020 May 21;15(5): e0233668. https://doi.org/10.1371/journal.pone.0233668

26. Abuhammad S. Parents' knowledge and attitude towards COVID19 in children: A Jordanian Study. International Journal of Clinical Practice2020;11(5):13671- 13678. https://doi.org/10.1111/ijcp.13671

27. Turkish red crescents society (TRC), International Federation of Red Cross and Red Crescent Societies (IFRC). Impact of COVID19 on refugee populations benefitting from the emergency social safety net (NEET) programme, assessment report. Available from: https://media.ifrc.org/ifrc/wpcontent/uploads/sites/5/2020/05/Impact-of-COVID-19-onRefugee-Populations-Benefitting-from-ESSN-Programme.pdf [Accessed on 07 November 2020]

28. UNHCR, the UN refugee agency. UNHCR Turkey response during the COVID-19 pandemic, [Internet]. Available from: https://reporting.unhcr.org/sites/default/files/UNHCR\%20Turkey \%20COVID-19\%20Update\%20-\%20July\%202020.pdf [Accessed on 20 September 2020]. 